Original Article

\title{
Prevalence of intestinal parasitic diseases in school children of rural areas of district Lower Dir, Pakistan
}

\author{
Prevalência de doenças parasitárias intestinais em escolares de áreas rurais do distrito \\ de Lower Dir, Paquistão
}

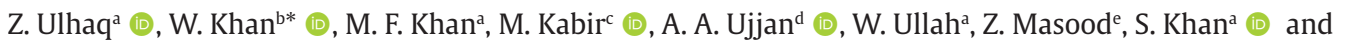 \\ P. De los Ríos Escalantef,g (D) \\ ${ }^{a}$ Hazara University, Department of Zoology, Mansehra, Pakistan \\ ${ }^{\mathrm{b}}$ University of Malakand, Department of Zoology, Malakand, Pakistan \\ c University of Sargodha, Department of Biological Sciences, Sub campus Bhakkar, Bhakkar-30000, Punjab, Pakistan \\ ${ }^{\mathrm{d}}$ University of Sindh, Institute of Plant Sciences, Jamshoro, Pakistan

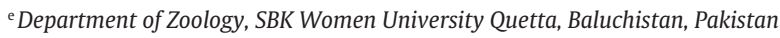 \\ f Universidad Católica de Temuco, Facultad de Recursos Naturales, Departamento de Ciencias Biológicas y Químicas, Casilla 15-D, Temuco, Chile \\ ${ }^{\mathrm{g}}$ Núcleo de Estudios Ambientales UC Temuco, Casilla, Temuco, Chile
}

\begin{abstract}
Present study was conducted among school children to recognize the prevalence of IPIs in rural communities of district Dir Lower, Pakistan. A sum of 324 samples of stool were collected ( 210 boys and 114 girls). Used direct smear method and formol ether sedimentation concentration technique for processing the samples. The result shows that $82 \%$ ( $n=266$ ) were found infected comprised $64.8 \%$ male and $35.1 \%$ females. Children of the age group 10 to 12 years were found extremely infected $94.2 \%$ while 4-6 year age group were having minimum ratio of infection $72 \%$. Current study shows mono parasitism in $50.6 \%$ of the students while $22.2 \%$ were infected with 2 species and $7.40 \%$ were infected with three species of parasites. Seven species of intestinal parasites were reported include Ascaris lumbricoid in male $(\mathrm{n}=122) 58.0 \%$ and in female $(\mathrm{n}=65) 57.0 \%$ followed by Hook worm $(\mathrm{n}=88) 41.9 \%$ and $(n=44) 38.5 \%$; Tania saginata $(n=44) 20.9 \%$ and $(n=24) 21.0 \%$; Entrobius vermicularis $(n=32) 15.2 \%$ and $(n=16) 14.0 \%$; Trichuris trichura $(n=25) 11.9 \%$ and $(n=22) 19.2 \%$; Hymenolepis nana $(n=24) 11.4 \%$ and $(n=18) 15.7 \%$ and Entameoba histolytica ( $n=16$ ) $7.61 \%$ and $(n=14) 12.2 \%$ in male and females respectively. The study indicates that most occurring intestinal parasite in the current study were Ascaris lumbricoides $58.0 \%(n=122)$ followed by hookworms $41.9 \%$ $(\mathrm{n}=88)$. Male students were more infected than females in the present study.
\end{abstract}

Keywords: intestinal parasite, infection, school children, Dir Lower, Pakistan.

\section{Resumo}

O presente estudo foi conduzido entre crianças em idade escolar para reconhecer a prevalência de IPIs em comunidades rurais do distrito de Dir Lower, Paquistão. Foram coletadas 324 amostras de fezes (210 meninos e 114 meninas). Método de esfregaço direto usado e técnica de concentração de sedimentação de formol éter para processar as amostras. 0 resultado mostra que $82 \%(n=266)$ dos infectados eram $64,8 \%$ do sexo masculino e 35,1\% do feminino. Crianças da faixa etária de 10 a 12 anos foram encontradas extremamente infectadas 94,2\%, enquanto a faixa etária de 4 a 6 anos apresentava proporção mínima de infecção de $72 \%$. 0 estudo atual mostra monoparasitismo em 50,6\% dos alunos, enquanto 22,2\% estavam infectados com 2 espécies e 7,40\% estavam infectados com três espécies de parasitas. Sete espécies de parasitas intestinais foram relatadas incluindo Ascaris lumbricoid em machos ( $n=122) 58,0 \%$ e em fêmeas $(n=65) 57,0 \%$ seguido por anzol $(n=88) 41,9 \%$ e $(n=44) 38,5 \%$; Tania saginata $(n=44) 20,9 \%$ e $(n=24) 21,0 \%$; Entrobius vermicularis $(n=32) 15,2 \%$ e $(n=16) 14,0 \%$; Trichuris trichura $(\mathrm{n}=25) 11,9 \%$ e $(\mathrm{n}=22) 19,2 \%$; Hymenolepis nana $(\mathrm{n}=24) 11,4 \%$ e $(\mathrm{n}=18) 15,7 \%$ e Entameoba histolytica $(\mathrm{n}=16) 7,61 \%$ e $(\mathrm{n}=14) 12,2 \%$ em homens e mulheres, respectivamente. 0 estudo indica que os parasitas intestinais que mais ocorreram no presente estudo foram Ascaris lumbricoides 58,0\% ( $n=122$ ), seguidos por ancilóstomos $41,9 \%(n=88)$. Estudantes do sexo masculino foram mais infectados do que do sexo feminino no presente estudo.

Palavras-chave: parasita intestinal, infecção, crianças em idade escolar, Dir Lower, Paquistão.

*e-mail: walikhan.pk@gmail.com

Received: September 3, 2020 - Accepted: November 16, 2020 


\section{Introduction}

Intestinal parasite in Pakistan is the main cause of morbidity also in India and Bangladesh and other emerging states but also is the common cause of death in developed countries (Liu et al., 2012). Parasites are mostly endemic and are widespread in some parts of the world so disease pattern varies in different geographic places. Helminth parasitic diseases are the topmost neglected tropical diseases (NTDs) comprised 24\% population in the world reported to be infected with helminth transmitted from soil.

Intestinal parasitic infection is widely spread in in China, East Asia, sub-Saharan Africa and Americas (WHO, 2018). In the ASEAN nations, it is expected that 300 million individuals are infected with intestinal helminth infections which is caused by soil transmitted helminth; specifically, A. lumbricoides infected 126.7 million people, T. trichiura infected 115.3 million and hookworm infected 77.0 million people (Hotez et al., 2015). Human being carry different kinds of parasites which contains both protozoan and helminth; protozoan include G. lambia, Cryptosporidium and $E$. histolytica species while helminths contain of roundworm such as flat worms and tape worm. Ascariasis, amoebiasis, trichuriasis, giardiasis and hookworm infection these disease are caused by different type of parasite and these are the main disease worldwide (NTDs) (WHO, 1987).

The common cause intestinal parasitic infections include improper sanitation and no access to safe drinking water. Individuals of all ages may get infection by the parasite with poor water and sanitation conditions but the small children are most vulnerable to the parasitic infection (Anwar et al., 2015). Due to the presence of parasitic infection the children have poor physical, mental and social health problem and poor job performance and loss of employment (Siddiqui et al., 2002). Under developed countries the poor people are susceptible to reoccurrence of under nourishment and constant infections prominent to more than necessary disease that can transfer from generation to generation (Mehraj et al., 2008). Causative agents of intestinal parasites for chronic diseases such as iron deficiency anemia, vitamin deficiencies, protein depletion, physical and mental health problems, stunted growth in children, diarrheal diseases, or even causes surgical problems like intestinal obstruction and increased susceptibility to other infections cognitive impairment and malnutrition (Quihui et al., 2006).

Major cases of IPIs are without symptoms and left long-lasting effects (Khan et al., 2004). The constipation, headache, intestinal discomfort, indigestion, nausea, cramps, diarrhea, reduced hunger and inflammation are the symptoms of IPIs. The sign and symptoms of IPIs are characteristically related with the symptoms of noncommunicable diseases, bacteria and viruses (Gordon and Cook, 2009). Anticipation of intestinal parasite comprise to improve environmental cleanness to increase hand washing facilities of the children and also stimulate children shoes wearing routines, promote education of the children at the initial age at the institution and at family, train the students about personal hygiene and providing clean drinking water (Gelaye et al., 2014).
Most of the studies have been conducted on intestinal parasitic infections in Pakistan time by time, however Malakand region the north west of Pakistan is also been screened as Khan et al. (2011, 2012, 2014, 2015, 2016, 2017a, b, 2018, 2019a, b, 2020) and Noor-un-Nisa et al. (2012).

Current study aimed to examine the prevalence of intestinal helminth and protozoans in school children of rural areas of district Dir Lower, Pakistan.

\section{Materials and methods}

\subsection{Area and climatic condition}

Dir Lower is limited in the South Malakand division, in the North it is meet with Dir Upper, in the East Swat and it is connected on its West to Bajawar. Afghanistan join the higher mountains of the north-west hilly areas. The altitude of area ranges from $1200 \mathrm{~m}$ to $2800 \mathrm{~m}$ asl. The weather of the District mainly depends on elevation. The $11.22^{\circ} \mathrm{C}$ and $2.39^{\circ} \mathrm{C}$ extreme and lowest temperature. The winter period is start from mid- November to March. According to census of 2017 the overall population of district Dir lower is 1435917 . Out of 1435917 the 710335 population of the male and the total population of the female were 725576 present in the district (Figure 1).

\subsection{Collection of stool sample}

School children of the study areas were informed to collect their stool samples. Stool sample were collected from both sexes of different age groups at primary schools of rural areas of district Dir Lower. Among the students dry, clean and appropriately labelled plastic bottle were distributed for the collection of stool sample. The plastic sample bottles accurately recognized by indicting code, tag, class, roll number sexes, age and their name. The plastic bottles were deliver a day earlier for the collection of stools samples. Students were being guide that stool not mix with water, urine or any mud. In the next morning the students who bring the bottle of stool sample we was reported their physical condition, weight and habits, family position joint family or not and their parent profession also noted their name, age, gender, class in the register. The collected stool sample were fixed in $10 \%$ formalin or formaldehyde and transfer to the Parasitology Laboratory, Department of Zoology, University of Malakand Dir Lower KPK Pakistan for parasite examination.

\subsection{Laboratory screening of stool samples}

First the stool sample examine by naked eye for the recognition of adult or any segmental phase of parasite. For the investigation of intestinal parasite, we were used two methods including direct smear method and formol ether sedimentation concentration method. In these cases, to increases the chances of detecting parasitic organisms we were used formol ether sedimentation concentration technique. In direct smear method we were take a $1 \mathrm{gm}$ of fecal material and small drop of $10 \%$ formalin and mixed $10 \%$ formalin and $1 \mathrm{gm}$ stool sample with the help of wooden applicator. After maxing the material we were 


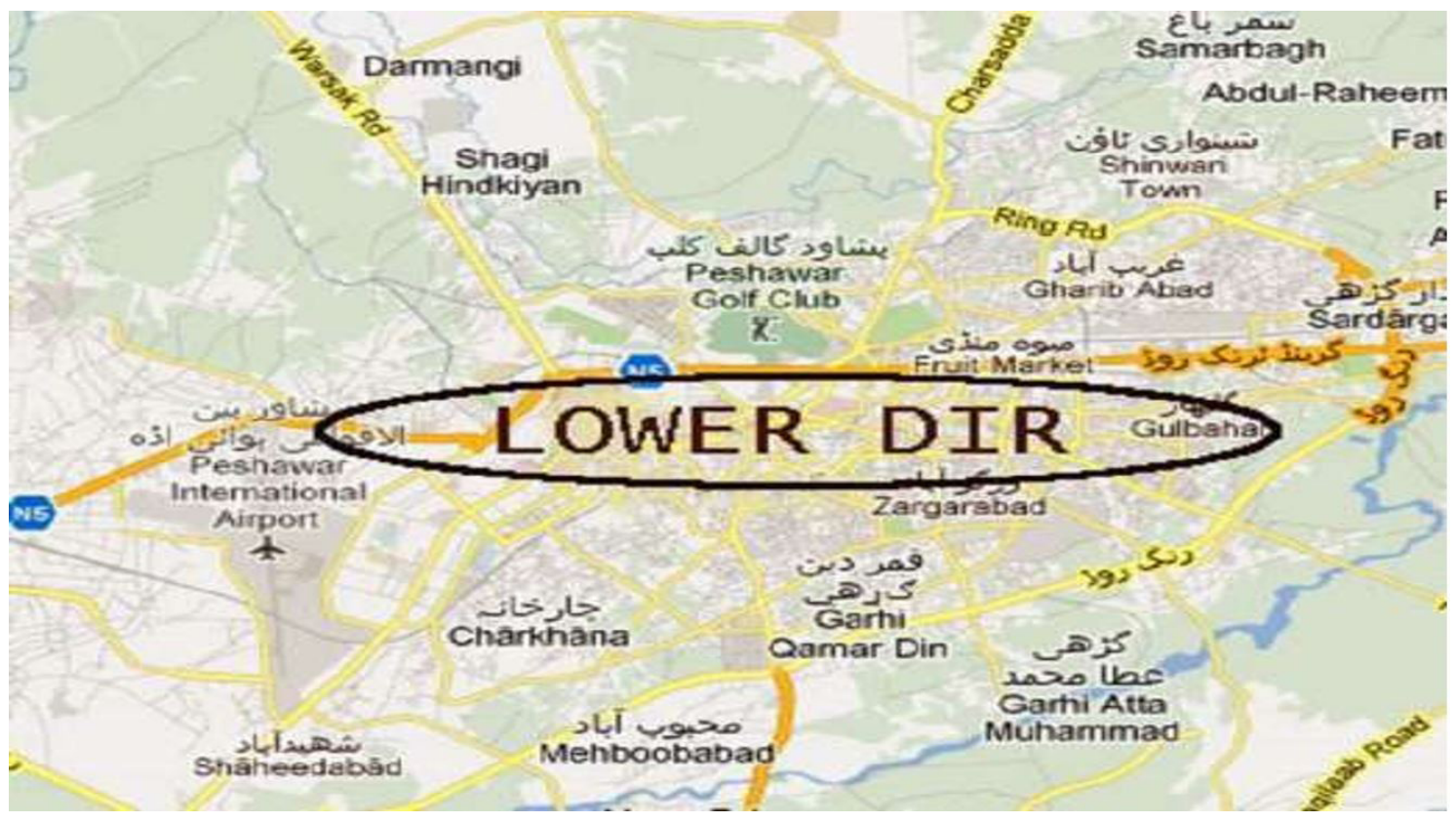

Figure 1. Parts of the region studied.

put one drop of liquid on the center of microscopic slide. Cover with a cover slip and slides were observed under microscope first under low power objective 10x and then 40x high power objective. Direct smear technique were used for the recognition of helminths egg.

\subsection{Statistical analysis}

Graph paid version 5 was used to analyze the data statistically, however we have considered P value significant when less than 0.05 .

\section{Results}

An overall 324 stool sample was collected from both boys and girls students of the rural area of district lower Dir. out of $324(n=210)$ stool sample were collected from boys student and $(n=114)$ stool sample were collected from girls. $64.8 \%(n=210)$ was the prevalence rate of IPIs in boys and $35.1 \%(n=114)$ prevalence rate in females. In current study boys were more infected as compared to girls. Two hundred and sixty six $(82.0 \%)$ were the total prevalence of infection. Seven species of intestinal parasites including A. lumbricoides (57.7\%) led by hook worm (40.7\%), T. saginata (20.9\%), E. vermicularis (14.8\%), T. trichura (14.5), H. nana (12.9\%) and E. histolytica (9.25\%) were reported. In relation to the age groups $10-12$ years children were found extremely infected as $94.2 \%$ ( $n=66$ ) followed by age group of 13 to 15 years as $92.8 \%(n=26)$ then the age group 7 to 9 years $84.4 \%(n=66)$ while 4 to 6 years age group were having low rate of infection $72 \%(n=98)$.

An overall 324 school children were selected for the occurrence of intestinal parasitic infections containing $(n=210) 64.8 \%$ boys and $(n=114) 35.1 \%$ was girls and $82.0 \%$
Table 1. Demographic features of the studied population.

\begin{tabular}{ccc}
\hline Characteristic & Number & Percent \\
\hline Boys & 210 & $64.8 \%$ \\
Girls & 114 & $35.1 \%$ \\
Mean \& Standard deviation & $162 \pm 67.8$ & \\
Total & 324 & 100 \\
\hline
\end{tabular}

was the total prevalence of intestinal parasite in the present study. $162 \pm 67.8$ were the Mean \& SD displayed (Table 1 ).

In the present study out of the total $82.0 \%$ were form positive for parasitic infection. This is comprising $(\mathrm{n}=176)$ $83.8 \%$ in boys and ( $n=90) 78.9 \%$ were girls students. $(n=34)$ $16.1 \%$ was found negative for boys and $(n=24) 21 \%$ in girls students in present study (Table 2 ). The association of the studied sample, positive and negative number of applicants were non-significant statistically $(\mathrm{P}>0.005)$.

Current study shows that a total of seven species of intestinal parasite were identified from both boys and girls children containing A. lumbricoides $(\mathrm{n}=122 \mathrm{~m}) 58.0 \%$ and $(\mathrm{n}=65 \mathrm{f}) 57.0 \%$; hook worms $(\mathrm{n}=88 \mathrm{~m}) 41.9 \%$ and $(\mathrm{n}=44 \mathrm{f})$ $38.5 \%$; T. saginata $(n=44 m) 20.9 \%$ and $(n=24 f) 21.0 \%$; E. vermicularis $(\mathrm{n}=32 \mathrm{~m}) 15.2 \%$ and $(\mathrm{n}=16 \mathrm{f}) 14.0 \%) ;$ T trichura $(\mathrm{n}=25 \mathrm{~m}) 11.9 \%$ and $(\mathrm{n}=22 \mathrm{f}) 19.2 \%$; . nana $(\mathrm{n}=24 \mathrm{~m}) 11.4 \%$ and $(\mathrm{n}=18 \mathrm{f}) 15.7 \%$ and E. histolytica $(\mathrm{n}=16 \mathrm{~m}) 7.61 \%$ and $(\mathrm{n}=14 \mathrm{f})$ $12.2 \%$ individually (Table 3 ). The relationship among boys and girls students for the total parasites identified is nonsignificant statistically ( $\mathrm{P}>0.005)$.

In school children age is a strong sign of disease occurrence that why the occurrence of intestinal parasites were studied in school going children of rural area of District lower Dir. In both sexes maximum students were contributed in 4 to 6 years age group then 7 - 9 years age group, 10 to 12 year and 13-15 years of age group 
(Table 4). The relationship between age groups and sexes of the applicants was not significant statistically $(\mathrm{P}>0.005)$.

In the current study school children of 10-12 years age group was found greatly infected $(n=66) 94.2 \%$ with intestinal parasite infection which is led to the age group of 13 to 15 year $(n=26) 92.8 \%$ then $7-9$ year age group $(n=66)$ $84.4 \%$ while the age group 4 to 6 year $(n=98) 72 \%$ having low rate of infection in school going children of rural area of Dir Lower. 13-15 year age group children were identified to be highly uninfected $(n=22) 78.5 \%$ which is followed by the age group of $10-12$ year $(n=16) 22.8 \%$, age group of 7-9 year $(n=8) 8.88 \%$ while $4-6$ year age group having minimum rate of uninfected $(n=12) 8.82 \%$ in the current study (Table 5). The relationship among infected and noninfected applicants were highly significant $(\mathrm{P}>0.001)$.

Out of 266 infected school children, ( $n=164) 50.6 \%$ were found infested with single parasite species.

Table 2. Gender wise prevalence of IPIs among school children at district Lower Dir, Pakistan.

\begin{tabular}{ccccc}
\hline Sex & Number studied & Number positive & Number negative & P Value (95\%CI) \\
\hline Boys & 210 & $176(83.8)$ & $34(16.1)$ & $0.3790,2$ \\
Girls & 114 & $90(78.9)$ & $24(21)$ & \\
Mean \& SD & $162 \pm 67.8$ & $132 \pm 59.3$ & $30 \pm 8.4$ & \\
Total & 324 & $266(82.0)$ & $58(17.9)$ & \\
\hline
\end{tabular}

95\% CI: Level of significance.

Table 3. Gender wise prevalence of IPIs amongst school children in rural areas of Lower Dir, Pakistan.

\begin{tabular}{lccccccc}
\hline \multicolumn{1}{c}{ Parasite species } & Boys & \% & Girls & \% & Total & \% & P Value (95\%CI) \\
\hline A.lumbricoides & 122 & 58.0 & 65 & 57.0 & 187 & 57.7 & 0.5088 \\
T.trichura & 25 & 11.9 & 22 & 19.2 & 47 & 14.5 & \\
E. vermicularis & 32 & 15.2 & 16 & 14.0 & 48 & 14.8 & \\
Hook worm & 88 & 41.9 & 44 & 38.5 & 132 & 40.7 & 20.9 \\
T. saginata & 44 & 20.9 & 24 & 21.0 & 68 & 12.9 \\
H. nana & 24 & 11.4 & 18 & 15.7 & 42 & 30 & 9.25 \\
E. histolytica & 16 & 7.61 & 14 & 12.2 & 30 \\
Mean \& SD & $50.1 \pm 39.6$ & & $29 \pm 18.7$ & & & & \\
\hline
\end{tabular}

Table 4. In relation to gender and age the IPIs amongst school children at district Lower Dir, Pakistan.

\begin{tabular}{ccccccc}
\hline S. No. & Age group & Boys & Girls & Total & Percent & P Value (95\% CI) \\
\hline 1 & $4-6$ & 92 & 44 & 136 & 41.9 & \\
2 & $7-9$ & 58 & 32 & 90 & 27.7 & 0.7234 \\
3 & $10-12$ & 44 & 26 & 70 & 21.6 & \\
4 & $13-15$ & 16 & 12 & 28 & 8.64 & \\
& & $52.2 \pm 31.5$ & & $81 \pm 44.8$ & & \\
\hline
\end{tabular}

S: Serial.

Table 5. Prevalence of intestinal parasitic infection in relation to the age groups of school children at rural areas of district Lower Dir, Pakistan.

\begin{tabular}{cccccccc}
\hline Age (Years) & Infected & $\%$ & Uninfected & $\%$ & Total & \% & P Value (95\%CI) \\
\hline $4-6$ & 98 & 73 & 12 & 8.82 & 136 & 41.9 & $<0.0001$ \\
$7-9$ & 76 & 84.4 & 8 & 8.88 & 90 & 27.7 & \\
$10-12$ & 66 & 94.2 & 16 & 22.8 & 70 & 21.6 & \\
$13-15$ & 26 & 92.8 & 22 & 78.5 & 28 & 8.64 & \\
$1-15$ & 266 & 82.0 & 58 & 17.9 & 324 & 100 & \\
& $66.5 \pm 30.1$ & & $14.5 \pm 5.9$ & & & & \\
\hline
\end{tabular}


The mono parasitism was recorded in the present study as A. lumbricoides ( $n=82) 25.3 \%$ led by Hook worms $(n=40)$ $12.3 \%$; T. trichura $(n=13) 4.01 \%$; H. nana $(n=12) 3.70 \%$; T. saginata $(n=6) 1.85 \%$; E. vermicularis $(n=6) 1.85 \%$ and E. histolytica $(\mathrm{n}=5) 1.54 \%$ respectively reported in the present study. The most frequent intestinal parasite in the current study were $A$. lumbricoid ( $n=82$ ) $25.3 \%$ trailed by Hook worm $(n=40) 12.3 \%$ and the minimum parasite in the current study were E. histolytica $(n=5) 1.54 \%$ recorded mono parasitic infection shown in (Table 6).

Out of 266 infected school children, (n=104) 32.0\% were found to be infected with poly parasitism infection. The poly parasitism of two species $(n=72) 22.2 \%$ were noted as hook worm $+A$. lumbricoides $(n=20) 6.17 \%$, T. trichiura $+E$. vermicularis $(\mathrm{n}=15)$ 4.62, Hook worm + A. lumbricoides $(n=12) 3.70 \%$, E histolytica + A. lumbricoides $(n=10) 3.08 \%$,

Table 6. Mono parasitism of intestinal parasite infection in school children of rural area of district Lower Dir, Pakistan.

\begin{tabular}{|c|c|c|c|}
\hline Types of infection & Species No. & Species & No. (\%) \\
\hline \multirow[t]{7}{*}{ Mono-parasitism } & one species $(n=164)$ & Ascaris lumbricoides & $82(25.3)$ \\
\hline & & Hook worm & $40(12.3)$ \\
\hline & & T.trichura & $13(4.01)$ \\
\hline & & E.vermicularis & $06(1.85)$ \\
\hline & & T. saginata & $06(1.85)$ \\
\hline & & H. nana & $12(3.70)$ \\
\hline & & E. histolytica & $05(1.54)$ \\
\hline Total Mano-parasitism & & & $164(50.6)$ \\
\hline Total infected student & & & $266(82.0)$ \\
\hline
\end{tabular}

Table 7. Poly parasitism of intestinal parasite infection in school going children of rural area of District Lower Dir, Pakistan.

\begin{tabular}{|c|c|c|c|}
\hline Poly-parasitism & 2 Species $(n=72)$ & Parasites & Prevalence \\
\hline & & H-worm + A-lumbricoides & $20(6.17)$ \\
\hline & & $H$-nana + A-lumbricoides & $12(3.70)$ \\
\hline & & E- histolytica + A-lumbricoides & $10(3.08)$ \\
\hline & & $H$-nana $+H$-worm & $08(2.46)$ \\
\hline & & E-vermicularis $+T$-trichura & $15(4.62)$ \\
\hline & & E-vermicularis $+E$-histolytica & $07(2.16)$ \\
\hline \multirow[t]{7}{*}{ Sub total } & & & $72(22.2)$ \\
\hline & 3 species $n=24$ & $H$ - nana $+H$-worm A-lumbricoides & $11(3.39)$ \\
\hline & & E-histolytica $+H$-worm $+A$ - lumbricoides & $05(1.54)$ \\
\hline & & $T$ - trichura $+H$ - nana $+A$ - lumbricoides & $02(0.61)$ \\
\hline & & E-vermicularis $+H$-nana $+H$ - worm & $04(1.23)$ \\
\hline & & $T$ - saginata $+E$ - vermicularis $+E$ - histolytica & $01(0.30)$ \\
\hline & & $T$ - saginata $+E$-vermicularis $+E$ - histolytica & $01(0.30)$ \\
\hline \multirow[t]{5}{*}{ Sub total } & & & $24(7.40)$ \\
\hline & 4 species $n=08$ & & \\
\hline & & $H$-nana $+E$-histolytica $+H$ - worm A-lumbricoides & $04(1.23)$ \\
\hline & & E-vermicularis $+H$-nana $+H$-worm $+A$-lumbricoids & $03(0.92)$ \\
\hline & & $T$-saginata $+T$-trichura $+H$-nana $+A$-lumbricoides & $01(0.30)$ \\
\hline Sub total & & & $08(2.46)$ \\
\hline Total parasitism & & & $104(32.0)$ \\
\hline Total infected student & & & $266(82.0)$ \\
\hline Total sample examined & & & 324 \\
\hline
\end{tabular}


H. nana + Hook worm $(\mathrm{n}=8) 2.46 \%$ and E. vermicularis + E. histolytica $(n=7) 2.16 \%$ were recorded. Poly parasitism of the three species $(n=24) 7.40 \%$ were noted as $H$. nana + Hook worm + A. lumbricoid ( $n=11) 3.39 \%$, E. histolytica + Hook worm + A. lumbricoid $(\mathrm{n}=5) 1.54 \%$, T. trichura + H. nana + A. lumbricoides $(\mathrm{n}=2) 0.61 \%$, E. vermicularis $+H$. nana + Hook worm $(\mathrm{n}=4) 1.23 \%$ and $T$. saginata + E. histolytica + E. vermicularis $(n=1) 0.30 \%$. The poly parasitism of 4 species $(n=8) 2.46 \%$ were noted as $H$. nana + E. histolytica + A. lumbricoides+ Hook worm $(n=4) 1.23 \%$, E. vermicularis $+H$. nana + A. lumbricoides + Hook worm $(n=3) 0.92 \%$ and T. saginata $+H$. nana + A. lumbricoides $+T$. trichura $+(\mathrm{n}=1)$ $0.30 \%$ was identified in the current study (Table 7 ).

\section{Discussion}

The most important intestinal parasites observed in both boys and girls A. lumbricoides, hookworm, T. trichura, H. nana, E. vermicularis, T. saginata and E. histolytica in our study. $(82.0 \%)(n=324 / 266)$ were the total prevalence of the intestinal parasite in present study, our finding result were lower than the study lead by Khan et al.(2017c) which shows the total prevalence of IP were $83.1 \%$. Other study directed from different country which shows different result study from Ethiopia which shows the total occurrence of IPIs was $28.0 \%$ (Alemnew et al., 2020). Chelkeba et al. (2020) described that the total occurrence of IPIs were $48 \%$ noted from Ethiopia while $12.4 \%$ prevalence of intestinal parasitic infection was reported from Karachi Pakistan by Arshad et al. (2019), 62.3\% prevalence of IPIs were reported from Malakand region by Khan et al. (2019, 40\% incidence of intestinal parasite infection were noted from Nepal by Gurung et al. (2019), 24.8\% occurrence of IP were noted from Ombda by Elameen et al. (2019), from Malaysia by Rajeswari et al. (1994) noted 62.9\% occurrence of intestinal parasite, $62.4 \%$ prevalence of IPIs reported from southeast Ethiopia by Sitotaw and Shiferaw (2020). The differences in results are due to the environmental locality, socio financial position and living habit of the study inhabitants.

A. lumbricoides were the most occurring intestinal parasite in the present study was in both boys and girls students, in boys student $58.09 \%(\mathrm{n}=122)$ and girls student $57.01 \%(n=65)$ which was found to be higher than the study lead by Khan et al. (2017c) from Swat which shows 55.8\% prevalence. From Ethiopia Sitotaw and Shiferaw (2020) reported $22.7 \%$ occurrence rate, $0.5 \%$ prevalence reported by Elameen et al. (2019) from Ombda, 86.3\% occurrence of A. lumbricoides reported from Quetta Pakistan by Zahir et al. (2020), Alemnew et al. (2020) described 4.12\% from Ethiopia, Arshad et al. (2019) reported 5.5\% from Karachi, Khan et al. (2018); 7.76\% reported from Swat, Feleke et al. (2019) reported 8.5\%prevalence of $A$. lumbricoides from Ethiopia. The second most prevalent intestinal parasite in the present study was hookworm in both boys and girls students, in boys $41.90 \%(n=88)$ and girls student $38.59 \%(n=44)$. This finding report is higher than the study conducted by Khan et al. (2017c) in the food handler of Swat which shows 5.99\% prevalence. Ullah et al. (2014) reported $54.50 \%$ prevalence from Upper Dir Pakistan. Gurung et al. (2019) from Nepal reported 3.85\%, 20.6\% from Ethiopia reported by Sitotaw and Shiferaw (2020); Arshad et al. (2019) reported 0.4\% from Karachi, Khan et al. (2019a); noted $50.4 \%$ from Swat. The third most prevalent parasite in the present study was $T$. saginata which is present in both boys and girls. $T$. saginata was found $20.9 \%(n=44)$ in boys and Girls $21.0 \%(n=24)$. This finding is higher than the study conducted by Khan et al. (2017b) which shows $8.98 \%(n=24)$ prevalence which is lower than our study. In Pakistan the prevalence of $T$. saginata was reported in different places in Karachi Pakistan 0.4\% reported by (Arshad et al., 2019); Zahir et al. (2020) described 4.5\% from Quetta, Kosar et al. (2017) noted 0.7\% from Punjab Pakistan, 0.5\% reported from ombda by Elameen et al. (2019), Amuta et al. (2017) noted 3.6\% from Nigeria. The fourth most prevalent intestinal parasite in both boys and girls student were recorded is E. vermicularis which shows the overall prevalence $14.8 \%(n=48)$ in the present study. In male student the prevalence of E. vermicularis was $15.2 \%(n=32)$ reported in girls student $14.0 \%(n=16)$. A study reported in Dir upper which shows the prevalence E. vermicularis was $1.3 \%$ which is much lower than the present study. The other most prevalent parasite in our study was $T$. trichura which are reported from both boys and girls students. In the boys the prevalence of T. trichura was reported is $11.9 \%(n=25)$ in girls students $19.2 \%$ ( $n=22$ ). Different study conducted in Pakistan which shows varies prevalence ratio like Khan et al. (2017b) described 26.5\% from Swat, Zahir et al. (2020) noted 9.0\% from Quetta, Sitotaw and Shiferaw (2020) 7.6\% reported from Ethiopia stated 6.67\%, (Kosar et al., 2017) reported $1.3 \%$, (Khan et al., 2018) reported $11.1 \%$. Other parasite include $H$. nana was also reported in our study in both girls and boys student. The prevalence of $H$. nana was reported in boys student is $11.4 \%(n=24)$ and girls student $15.7 \%(n=18)$. The prevalence of $H$. nana is higher in girls student is compare to boy's students. Arshad et al. (2019) reported 1.8\%, Elameen et al. (2019) reported 6.7\%, Sitotaw and Shiferaw (2020) 5.7\% noted from Ethiopia (Khan et al., 2018) stated $2.77 \%$.

In both of the gender most of the schoolchildren were contributed in age group 4 to 6 years trailed by 7 to 9 years, 10-12 and 13 to 15 years of ages. In the current study 10-12 years age group students were found highly infected which shows ( $n=66$ ) $94.2 \%$ with Intestinal parasite infection which is followed by the age group of 13 to 15 year which were ( $n=26$ ) $92.8 \%$ then 7 to 9 year age group which was $84.4 \%$ $(n=66)$ while ( $n=98) 72 \%$ the age group 4 to 6 years were having low level of infection. Age group 13 to 15 year student was found to be extremely uninfected $(n=22) 78.5 \%$ which is trailed by the age group of 10 to 12 year which was $(n=22)$ $22.8 \%$ than $7-9$ year age group which show $(n=8) 8.88 \%$ while the 4 to 6 year age group were having low ratio of uninfected which show ( $n=12) 8.82 \%$ were noted in the current study.

Our result compare with the study conducted in Dir Upper which show that The age group 13-15 in male children show highest prevalence (93.75\%) was reported which is followed by age group 4-6 years which show $(83.33 \%)$ than show $(81.82 \%)$ of the age group of $10-12$ and age group 7-9 (80\%) in female children. The highest infection, were observed in children with the age of 1315 year which shows $88.89 \%(n=18)$, while the age group 
10-12 year have low infection of parasite. Another study conducted by Siddig et al. (2017) which show that the age group of 5-7 year show $82.50 \%$ was more infected which is followed by 8 - 11 year which show $70.50 \%$ than $12-14$ year age show $55.50 \%$ prevalence. Dudlova et al. (2016) reported that the maximum occurrence of protozoan infections $3.27 \%$ was found in the age group $8-18$ year and helminthic infections $5.84 \%$ in the lowest rate of infection at the age of 1 month to 7 years. Elameen et al. (2019) reported that the $6-8$ years age groups have highest prevalence rate (35\%), while the 6-8 years age groups have lowest prevalence rate $(10.3 \%)$ was reported.

On the basis of sex wise, the prevalence of parasitic infection in the male student $64.8 \%(n=210)$ was higher than female students which show 35.1\% ( $n=114)$. This finding is compare with other study. Study conducted in Muzaffarabad which show 31.6\% male and 26.5\% female student prevalence (Chaudhry et al., 2004). Another study conducted by Golia et al. (2014) which show that $36.18 \%$ prevalence in male student and $13.20 \%$ prevalence were reported in female student in Bangalore. Females children were found more infected s compared to males (Khan et al., 2015); $18.9 \%$ reported in male and $20.7 \%$ in female; $58.5 \%$ reported in male and $80.3 \%$ prevalence reported in female (Rai et al., 2017); $27.56 \%$ in male and $33.90 \%$ reported the prevalence in female. The high prevalence in male student in our study due to playing habit in outside the home and works in soil field is compare to female students.

\section{References}

ALEMNEW, B., GEDEFAW, G., DIRESS, G. and BIZUNEH, A.D., 2020 Prevalence and factors associated with intestinal parasitic infections among food handlers working at higher public University student's cafeterias and public food establishments in Ethiopia: a systematic review and meta-analysis. BMC Infectious Diseases, vol. 20, no. 1, pp. 1-12. http://dx.doi.org/10.1186/ s12879-020-4884-4. PMid:32075585.

AMUTA, E.A.O., IBOYI, M. and AJANGEM, S., 2017. A comparative study of gastrointestinal parasites among secondary school students in the rural and urban communities of Makurdi local government. International Journal of Tropical Disease \& Health, vol. 25, no. 4, pp. 1-9. http://dx.doi.org/10.9734/IJTDH/2017/35669.

ANWAR, S., SAAD, U. and BASIT, Z., 2015. Frequency of pathogenic stool parasites in patients from a tertiary care hospital in Karachi. Infectious Diseases Journal of Pakistan, vol. 24, no. 2, pp. 803-815.

ARSHAD, S., KHATOON, N., WARIND, J.A., KHAN, A., WAHEED, S. and KHAN, W., 2019. The prevalence of human intestinal protozoal and helminthic infection in Karachi. International Journal of Biology and Biotechnology, vol. 16, no. 2, pp. 319-323.

CHAUDHRY, Z.H., AFZAL, M. and MALIK, M.A., 2004. Epidemiological factors affecting prevalence of intestinal parasites in children of Muzaffarabad district. Pakistan Journal of Zoology, vol. 36, no. 4, pp. 267-271.

CHELKEBA, L., MEKONNEN, Z., ALEMU, Y. and EMANA, D., 2020. Epidemiology of intestinal parasitic infections in preschool and school-aged Ethiopian children: a systematic review and meta-analysis. BMC Public Health, vol. 20, no. 1, pp. 117. http:// dx.doi.org/10.1186/s12889-020-8222-y. PMid:31992252.
DUDLOVÁ, A., JURIŠ, P., JURIŠOVÁ, S., JARČUŠKA, P. and KRČMÉRY, V., 2016. Epidemiology and geographical distribution of gastrointestinal parasitic infection in humans in Slovakia. Helminthologia, vol. 53, no. 4, pp. 309-317. http://dx.doi.org/10.1515/helmin-2016-0035.

ELAMEEN, A.S.M., HAMAD, M.N.M. and ELDIN, M.B., 2019. Prevalence of intestinal parasitic infections among primary schools aged children in ombda locality. Saudi Journal of Biomedical Research, vol. 4, no. 12, pp. 412-415. http://dx.doi.org/10.36348/sjbr.2019.v04i12.001.

FELEKE, B.E., BEYENE, M.B., FELEKE, T.E., JEMBER, T.H. and ABERA, B., 2019. Intestinal parasitic infection among household contacts of primary cases, a comparative cross-sectional study. PLoS One, vol. 14, no. 10, pp. e0221190. http://dx.doi.org/10.1371/ journal.pone.0221190. PMid:31589618.

GELAYE, B., KUMIE, A., ABOSET, N., BERHANE, Y. and WILLIAMS, M.A., 2014. School-based intervention: evaluating the role of water, latrines and hygiene education on trachoma and intestinal parasitic infections in Ethiopia. Journal of Water, Sanitation, and Hygiene for Development : a Journal of the International Water Association, vol. 4, no. 1, pp. 120-130. http://dx.doi.org/10.2166/ washdev.2013.060. PMid:25859318.

GOLIA, S., SANGEETHA, K.T. and VASUDHA, C.L., 2014. Prevalence of parasitic infections among primary school children in Bangalore. International Journal of Basic and Applied Medical Sciences, vol. 4, no. 1, pp. 356-361.

GORDON, C. and COOK, N., 2009. Tropical gastro entero logical, In: G.C. COOK and A. I. ZUMLA, eds. Manson's textbook of tropical diseases. Edinburgh: Saunders, pp. 107-136, no. 22.

GURUNG, B., SUBEDI, J.R. and CHHETRI, B., 2019. Prevalence of intestinal parasites among public and private school children below 10 years' at Tarakeswor-10 Manamaiju, Kathmandu, Nepal. National Journal of Health Sciences, vol. 4, no. 3, pp. 97102. http://dx.doi.org/10.21089/njhs.43.0097.

HOTEZ, P.J., BOTTAZZI, M.E., STRYCH, U., CHANG, L.Y., LIM, Y.A., GOODENOW, M.M. and ABUBAKAR, S., 2015. Neglected tropical diseases among the Association of Southeast Asian Nations (ASEAN): overview and update. PLoS Neglected Tropical Diseases, vol. 9, no. 4, pp. e0003575. http://dx.doi.org/10.1371/journal. pntd.0003575. PMid:25880767.

KHAN, A., KHAN, A., SULTANA, A., DAR, A.M.K., RASHID, H. and NAJMI, S.A.A., 2004. A study of prevalence distribution and risk factors of intestinal helminthic infestation in district Bagh [Azad Kashmir]. Pakistan Armed Forces Medical Journal, vol. 54, no. 2, pp. 243-248.

KHAN, W., IMRAN and WAHAB, A., 2016. Intestinal obstruction by Ascaris lumbricoides in a 12 year old boy: a case report in Pakistan. Journal of Bacteriology \& Parasitology, vol. 7, no. 1, pp. 262. http://dx.doi.org/10.4172/2155-9597.1000262.

KHAN, W., IQBAL, M. and DAD, O., 2020. Have We Forgotten the Threat Posed by Fascioliasis? A Potential Threat to Public Health. Iranian Journal of Public Health, vol. 49, no. 4, pp. 814815. PMid:32548067.

KHAN, W., KHAN, J., KHAN, N., IQBAL, R., ULLAH, A., GHAFFAR, R., MEHMOOD, S.A., AHMAD, S., KHAN, S. and ULLAH, F., 2019b. Soil-transmitted helminth infections in school children of three districts of Malakand region, Khyber Pakhtunkhwa, Pakistan. Pakistan Journal of Pharmaceutical Sciences, vol. 32, no. 2, suppl., pp. 799-803. PMid:31103975.

KHAN, W., KHAN, N.I., BUKHARI, S.N.F. and BEGUM, N., 2019a. Prevalence of intestinal parasitic infection among drug addicts in District Swat, Khyber Pakhtunkhwa, Pakistan. Iranian Journal of Parasitology, vol. 14, no. 2, pp. 359-361. PMid:31543928.

KHAN, W., MUMTAZ, G., BIBI, S. and AFZAL, S., 2017a. Parasitic contamination of fresh vegetables sold at upper and lower Dir Districts, Khyber Pakhtunkhwa, Pakistan. Pakistan Journal of 
Zoology, vol. 49, no. 3, pp. 1115-1118. http://dx.doi.org/10.17582/ journal.pjz/2017.49.3.sc3.

KHAN, W., NISA, N. and KHAN, A., 2017b. Soil transmitted helminthiasis in different occupational groups in Swat, Khyber Pakhtunkhwa, Pakistan. Pakistan Journal of Pharmaceutical Sciences, vol. 30, no. 4, pp. 1345-1350. PMid:29039336.

KHAN, W., NISA, N. and KHAN, A., 2017c. Prevalence and risk factors associated with intestinal parasitic infections among food handlers of Swat, Khyber Pakhtunkhwa, Pakistan.Journal of Food and Nutrition Research, vol. 5, no. 5, pp. 331-336. http:// dx.doi.org/10.12691/jfnr-5-5-7.

KHAN, W., NISA, N.-U. and NAWAZ, M.A., 2018. Incidence of tapeworm infection in human population of Swat, Pakistan: an occupation based study. Pakistan Journal of Zoology, vol. 50, no. 2, pp. 639-645. http://dx.doi.org/10.17582/journal. pjz/2018.50.2.639.645.

KHAN, W., NOOR-UN-NISA and KHAN, A., 2011. An investigation of incidence of intestinal parasites in under and above 15 years age in farmers of Swat, Pakistan. Proceedings of Parasitology, vol. 52, pp. 43-53.

KHAN, W., NOOR-UN-NISA and KHAN, A., 2012. Endemicity of intestinal parasites with special reference to nematodes in individuals related to education (students, staff and teachers) in Swat, K.P.K, Pakistan. Pakistan Journal of Nematology, vol. 30, no. 1, pp. 77.

KHAN, W., NOOR-UN-NISA and KHAN, A., 2014. A case of Fasciola hepatica infection in Swat, Pakistan. Pakistan Journal of Zoology, vol. 46, no. 6, pp. 1789-1790.

KHAN, W., NOOR-UN-NISA and KHAN, A., 2015. Diversity of intestinal parasites in male and female students and workers of education Department of Swat, Pakistan. Pakistan Journal of Zoology, vol. 47, no. 2, pp. 565-568.

KOSAR, S., AFSHAN, K., SALMAN, M., RIZVI, S., NASEEM, A.A., FIRASAT, S., JAHAN, S., MILLER, J.E. and QAYYUM, M., 2017. Prevalence and risk factors associated with intestinal parasitic infections among schoolchildren in Punjab, Pakistan. Tropical Biomedicine, vol. 34, no. 4, pp. 770-780. PMid:33592946.

LIU, L., JOHNSON, H.L., COUSENS, S., PERIN, J., SCOTT, S., LAWN, J.E., RUDAN, I., CAMPBELL, H., CIBULSKIS, R., LI, M., MATHERS, C. and BLACK, R.E., 2012. Global, regional, and national causes of child mortality: an updated systematic analysis for 2010 with time trends since 2000. Lancet, vol. 379, no. 9832, pp. 2151-2161. http:// dx.doi.org/10.1016/S0140-6736(12)60560-1. PMid:22579125.

MEHRAJ, V., HATCHER, J., AKHTAR, S., RAFIQUE, G. and BEG, M.A., 2008. Prevalence and factors associated with intestinal parasitic infection among children in an urban slum of Karachi. PLoS One, vol. 3, no. 11, pp. e3680. http://dx.doi.org/10.1371/journal. pone.0003680. PMid:18997865.
NOOR-UN-NISA, KHAN, W. and KHAN, A., 2012. A prevalence of intestinal parasites in male and female shepherds of Swat, Pakistan. International Journal of Biology and Biotechnology, vol. 8, no. 4, pp. 597-603.

QUIHUI, L., VALENCIA, M.E., CROMPTON, D.W., PHILLIPS, S., HAGAN, P., MORALES, G. and DÍAZ-CAMACHO, S.P., 2006. Role of the employment status and education of mothers in the prevalence of intestinal parasitic infections in Mexican rural schoolchildren. BMC Public Health, vol. 6, no. 1, pp. 225. http:// dx.doi.org/10.1186/1471-2458-6-225. PMid:16956417.

RAI, L., SAUD, B., PAUDEL, G. and DHUNGANA, G., 2017. Prevalence of intestinal parasitic infection among rural area school children of Lokhim VDC, Nepal. Journal of Microbiology E'Experimentation, vol. 4, no. 1, pp. 00102.

RAJESWARI, B., SINNIAH, B. and HUSSEIN, H., 1994. Socio-economic factors associated with intestinal parasites among children living in Gombak, Malaysia. Asia-Pacific Journal of Public Health, vol. 7, no. 1, pp. 21-25. http://dx.doi.org/10.1177/101053959400700104. PMid:8074940.

SIDDIG, H.S., MOHAMMED, I.A., MOHAMMED, M.N. and BASHIR, A.M., 2017. Prevalence of intestinal parasites among selected group of primary school children in Alhag Yousif Area, Khartoum, Sudan. International Journal of Medical Research E'Health Sciences, vol. 6, no. 8, pp. 125-131.

SIDDIQUI, M.I., BILQEES, F.M., ILIYAS, M. and PERVEEN, S., 2002. Prevalence of parasitic infections in a rural area of Karachi, Pakistan. The Journal of the Pakistan Medical Association, vol. 52, no. 7, pp. 315-320. PMid:12481664.

SITOTAW, B. and SHIFERAW, W., 2020. prevalence of intestinal parasitic infections and associated risk factors among the first-cycle primary schoolchildren in Sasiga District, Southwest Ethiopia. Journal of Parasitology Research, vol. 2020, pp. 8681247. http://dx.doi.org/10.1155/2020/8681247. PMid:32231795.

ULLAH, W., SHAH, A., JAMAL, Q., ULLAH, S., MUHAMMAD, I. and ULLAH, H., 2014. Prevalence of intestinal parasites among school children in District Upper Dir, Khyber Pakhtunkhwa Pakistan. IJB, vol. 5, no. 1, pp. 1-8. http://dx.doi.org/10.12692/ijb/5.1.1-8.

WORLD HEALTH ORGANIZATION - WHO, 1987. Public health significance of intestinal parasitic infections. Bulletin of the World Health Organization, vol. 65, no. 5, pp. 575-588. PMid:3501340.

WORLD HEALTH ORGANIZATION - WHO, 2018 [viewed 10 May 2018]. Soil- transmitted helminthic infections. Geneva: WHO. Available from: http://www.who.int/news-room/fact-sheets/ detail/ soil-transmitted-helminth-infections

ZAHIR, A., TARIQ Z., MUHAMMAD, S.L., KAKAR, Z., NASEER, U. and TARIQ N., 2020. Prevalence of geo-helminths eggs and cysts in soil samples of different primary and high schools of QuettaPakistan. Pure and Applied Biology, vol. 9, no. 2, pp. 1341-1346. http://dx.doi.org/10.19045/bspab.2020.90140. 